\title{
Analisis faktor memilih karier jabatan fungsional pustakawan di Perpustakaan Pusat Universitas Padjadjaran
}

\author{
Muhammad Zeinuri Rahyudi ${ }^{1}$, Mulyani ${ }^{2}$, Yulianti ${ }^{3}$ \\ ${ }^{1}$ Perpustakaan Fakultas Ekonomi \& Bisnis (FEB) Universitas Padjadjaran \\ Jl. Dipati Ukur No. 35, Bandung, Jawa Barat, 40132 \\ 2,3Perpustakaan Pusat Universitas Padjadjaran \\ Jl. Raya Bandung-Sumedang Km. 21, Jatinangor, Sumedang, Jawa Barat, 45362

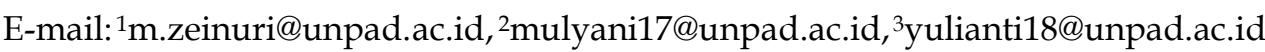

Received: August 2019; Accepted: December 2019; Published: December 2019

\begin{abstract}
Choosing the type of job for a civil servant is the first step to establishing a career. A civil servant can opt for several careers. One of which is the functional librarian, through the librarian at the skill level and the librarian at the expertise level. Many factors are the background of career selection for civil servants who choose the functional librarian so that the librarian profession can develop both in quantity and quality. This study aimed to determine the civil servant's factors choosing the functional librarian at Universitas Padjadjaran in Bandung. This research used a descriptive method through a qualitative approach, by distributing questionnaires conducted from December 7, 2017, to December 15, 2017. The total number of population sampel was 100 people. Based on the study results, the conclusions are that many of the a civil servant choose the functional librarian due leadership encouragement, to the opportunity to move up the rank/class faster and the expectation of increased income. The job for a civil servant choose the functional librarian because of the opportunity to move up the rank faster to increase income. In addition, educational staff as functional positions to get a level or a career that is better than the job previous condition. Meanwhile, the job for a civil servant basically already have expertise in the field of library science in the different degrees.
\end{abstract}

Keywords: Functional librarian position; Librarian; Universitas Padjadjaran

\begin{abstract}
Abstrak
Pemilihan jenis pekerjaan bagi seorang tenaga kependidikan negeri sipil merupakan langkah pertama untuk pembentukan karier. Ada beberapa opsi karier yang dapat diambil seorang tenaga kependidikan negeri sipil saat ini. Salah satunya adalah jabatan fungsional pustakawan, sebagai pustakawan tingkat terampil dan pustakawan tingkat ahli. Banyak faktor yang menjadi latar belakang pemilihan karier bagi seorang tenaga kependidikan negeri sipil memilih jabatan fungsional pustakawan sehingga sangat memungkinkan profesi pustakawan berkembang baik secara kuantitas maupun kualitas. Penelitian ini bertujuan untuk mengetahui, faktor tenaga kependidikan negeri sipil memilih jabatan fungsional pustakawan di Perpustakaan Pusat Universitas Padjadjaran Bandung. Penelitian ini menggunakan metode penelitian deskriptif melalui pendekatan kualitatif, dengan menyebarkan kuesioner yang dilakukan dari tanggal 7 Desember 2017 sampai dengan tanggal 15 Desember 2017. Adapun jumlah populasi sampel ialah berjumlah 100 orang. Berdasarkan hasil penelitian dapat disimpulkan bahwa faktor tenaga kependidikan dalam memilih jabatan fungsional pustakawan di Universitas Padjadjaran ada beberapa faktor, yaitu dorongan pimpinan, pangkat/golongan, dan penghasilan. Tenaga kependidikan memilih jabatan fungsional karena peluang lebih cepat naik pangkat/golongan untuk meningkatkan penghasilan. Selain itu, tenaga kependidikan sebagai jabatan fungsional untuk mendapatkan jenjang atau karir yang lebih baik dibandingkan kondisi pekerjaan sebelumnya. Adapun, tenaga kependidikan pada dasarnya sudah memiliki keahlian dalam bidang ilmu perpustakaan dalam gelar yang berbeda.
\end{abstract}

Kata Kunci: Jabatan fungsional pustakawan; Pustakawan; Universitas Padjadjaran 


\section{PENDAHULUAN}

Kementerian

Pendayagunaan Aparatur Negara dan Reformasi Birokrasi (PANRB) menghimbau agar segera melakukan pemetaan jabatan fungsional dan memetakan Tenaga kependidikan Negeri Sipil (PNS) di lingkungannya yang memenuhi syarat terkait dengan kebijakan inpassing nasional. Hal ini dalam rangka penataan Sumber Daya Manusia (SDM) di seluruh instansi pemerintah. Pemetaan jabatan fungsional ini perlu diselenggarakan menyusul terbitnya Peraturan Pemerintah No. 26/2016 tentang Pengangkatan PNS dalam Jabatan Fungsional melalui penyesuaian/inpassing.

Profesi pustakawan terkadang masih dipandang sebelah mata oleh sebagian masyarakat. Konstruksi pustakawan yang menggunakan kacamata dan berada di belakang meja diingat masyarakat dari film atau cerita fiksi pustakawan. Padahal, profesi pustakawan ialah profesi yang melayani pemustaka perpustakaan dengan penuh keikhlasan, sehingga profesi pustakawan dapat dimaknai,

"Pustakawan sebagai penolong, pustakawan sebagai pendidik, pustakawan sebagai teman diskusi, pustakawan sebagai konsultan, pustakawan sebagai pembimbing, pustakawan sebagai manajer informasi, pustakawan sebagai fasilitator informasi, pustakawan sebagai profesi yang menjanjikan" (Heriyanto, Yusup, \& Rusmana 2013).

Begitu pun pustakawan di Universitas Padjadjaran (UNPAD). Seseorang yang layak menduduki jabatan fungsional harus memiliki keahlian dan keterampilan tertentu yang dibutuhkan organisasi dalam rangka memperkuat organisasi melalui jabatan fungsional. Hal ini dilakukan untuk mendorong kuantitas jabatan fungsional dalam mendukung kinerja sebagai tulang punggung organisasi. Maka, penataan Sumber Daya Manusia (SDM) harus memperhatikan kualifikasi, kompetensi, dan kinerja tenaga kependidikan.

Universitas Padjadjaran, sejak 2012 telah mengangkat tenaga kependidikan Badan Layanan Umum (BLU) untuk memenuhi kebutuhan tenaga profesional yang tidak terpenuhi oleh PNS. Tenaga kependidikan BLU disebut Tenaga kependidikan Non PNS, yang direkrut berdasarkan persyaratan yang telah ditentukan, diangkat oleh pejabat yang berwenang, dan diberikan gaji sesuai ketentuan yang berlaku. Tenaga kependidikan BLU dibekali pengetahuan dan pemahaman tentang organisasi, tata kerja, serta tugas dan fungsinya sehingga mereka dapat mengetahui kewajiban yang harus dilaksanakan dan hak yang harus diterima sebagai tenaga kependidikan. Berbekal pengetahuan dan pemahaman tersebut maka para tenaga kependidikan dapat melaksanakan tugas atau pekerjaannya dengan baik, contohnya memiliki pengetahuan dan pemahaman sebagai pustakawan.

Sejatinya, pustakawan di dunia kepustakawanan memang harus mengikuti perkembangan teknologi informasi. Pustakawan sebagai agen perubahan dan pembaharuan dapat berkreasi menggunakan berbagai program dalam pengemasan informasi untuk dilayankan pada pemustaka. Pustakawan di bidang pendidikan dan pengajaran pun berperan sebagai penopang kebutuhan pokok bagi para pendidik dan peneliti. Para pustakawan 
dapat memudahkan penerimaan informasi yang dibutuhkan pemustaka. Dengan demikian, pustakawan dapat menjadi mediator dalam membantu pemustaka memperoleh informasi yang tidak dapat diakses secara umum.

Berdasarkan peran pustakawan di atas, Perpustakaan Pusat Universitas Padjadjaran pun berusaha meningkatkan kualitas pustakawan dan pelayanan perpustakaan kepada para pemustaka, melalui penambahan tenaga kependidikan. Perpustakaan Pusat Universitas Padjadjaran membuka kesempatan kepada tenaga kependidikan untuk melakukan inpassing melalui karir sebagai jabatan fungsional pustakawan. Ada beberapa motivasi bagi tenaga kependidikan memilih inpassing, misalnya jenjang karir yang bagus dan penambahan ekonomi melalui insentif. Namun

"Pemberian insentif ternyata tidak berpengaruh pada kinerja atau menjadi suatu hal yang dicari dalam menjadi jabatan fungsional pustakawan. Para jabatan fungsional pustakawan merasa insentif merupakan hak mereka. Jadi, dapat dikatakan pemberian insentif bukan merupakan faktor yang memengaruhi para tenaga pendidik untuk memilih karir jabatan fungsional pustakawan" (Dinahaji, 2012).

Selain itu, ada temuan penelitian yang mengatakan bahwa hal yang menjadi memotivasi seorang jabatan fungsional pustakawan dalam meningkatkan kinerja yaitu, "Kesejahteraan, lingkungan kerja, team work, pimpinan, karakteristik, dan jumlah pengunjung" (Martikasari, 2012). Faktor kesejahteraan merupakan tuntutan tenaga kependidikan ketika bekerja dapat memenuhi kebutuhan hidupnya. Secara lingkungan kerja pun, tenaga kependidikan mengharapkan lingkungan kerja yang mampu memberikan kenyamanan dalam bekerja. Kerja sama (team work) dapat dibangun melalui lingkungan kerja yang kondusif. Pimpinan di perpustakaan diharapkan seorang pemimpin yang dapat menjalin komunikasi yang bagus dengan pustakawan, salah satunya memberikan kebebasan pada pustakawan untuk berkreasi di perpustakaan sehingga meningkatkan jumlah pengunjung datang ke perpustakaan.

Perpustakaan Nasional Republik Indonesia memberikan keleluasaan bagi perpustakaan di semua kalangan untuk menambah jumlah pustakawan dari tenaga kependidikan berlatar belakang non-ilmu perpustakaan melalui penyesuaian/inpassing. Namun, kenyataannya ada perpustakaan yang menerapkan hal ini dan tidak, misalnya di perpustakaan perguruan tinggi.

Ada beberapa penelitian terkait perpustakaan perguruan tinggi yang melaksanakan program jabatan fungsional pustakawan. Kromosemito (2017) meneliti mengenai, "Motivasi tenaga kependidikan menjadi pustakawan melalui program jabatan fungsional pustakawan dengan usia pensiun yang lebih lama." Responden diteliti pada pustakawan inpassing yang memiliki latar belakang ijazah S1 sebanyak 43 orang. Hasil penelitian memperlihatkan bahwa, responden yang memilih jabatan fungsional pustakawan lebih besar motivasinya karena usia pensiun yang lebih lama.

Penelitian lainnya dari Nugrohoadhi (2014) mengenai alasan dan motivasi tenaga kependidikan mengikuti jabatan 
fungsional pustakawan di Perpustakaan Universitas Atma Jaya Yogyakarta. Sesuai hasil penelitian ini, didapatkan data bahwa jabatan fungsional pustakawan telah meningkatkan motivasi kinerja pustakawan, namun jabatan fungsional tidak efektif menaikkan kinerja di perpustakaan, dan menganggap bahwa tenaga kependidikan melalui jabatan fungsional pustakawan sebagai beban.

Bryan (2016) menambahkan bahwa ada beberapa alasan seseorang beralih fungsi jabatan pekerjaan menjadi pustakawan, di antaranya dipengaruhi faktor berikut; (1) pilihan antara tertahan atau membuat pilihan lain; (2) pekerjaan sebelumnya; (3) kebermanfaatan; (4) pengaruh dari orang lain; dan (5) lingkungan kerja. Hal senada diungkapkan Oliver and Prosser (2017) bahwa keputusan menjadi pustakawan dapat juga dipengaruhi oleh pustakawan lain, pekerjaan sebelumnya di perpustakaan, keputusan untuk membuat perubahan karier, proses eliminasi, penyelarasan kepentingan dan kemampuan menyelesaikan salah paham di lapangan. Namun, Oliver and Prosser (2018), dalam penelitiannya yang berbeda menyatakan kalau, faktor pekerjaan sebelumnya di perpustakaan akademik adalah faktor pendorong substansial untuk masuk ke lapangan. Hal ini terjadi dalam kasus pustakawan akademik tradisional yang memilih untuk mendapatkan gelar sarjana dalam ilmu perpustakaan sebelum mendapatkan posisi di perpustakaan.

Sesuai rujukan penelitian terdahulu di atas, penelitian Kromosemito (2017), Bryan (2016), Oliver and Prosser (2017), dan Oliver and Prosser (2018) menceritakan bahwa tenaga kependidikan yang memilih jabatan fungsional pustakawan memiliki motivasi karena ingin memperpanjang usia pensiun, perubahan karier, pengaruh lingkungan, dan latar belakang akademik yang sebelumnya sudah mengambil pendidikan ilmu perpustakaan namun tidak bekerja di perpustakaan. Penelitian Nugrohoadhi (2014) menambahkan bahwa ada peningkatkan motivasi tenaga kependidikan untuk memilih jabatan fungsional pustakawan namun tidak disertai peningkatan kinerja di perpustakaan. Hal ini mengakibatkan ada persepsi bahwa jabatan fungsional pustakawan sebagai beban bagi pustakawan di perpustakaan.

Sesuai temuan data penelitian menunjukkan bahwa ada dua jalur masuk utama bagi para profesional perpustakaan akademik yakni, tenaga kependidikan yang bekerja di posisi fungsional yang tidak memerlukan gelar sarjana dalam bidang kepustakawanan dan tenaga kependidikan yang memegang gelar paraprofessional, yang telah mengambil pekerjaan tingkat profesional. Hal ini memiliki penelitian yang berbeda namun menyiratkan hasil yang sama.

Dengan demikian, penelitian ini berfokus meneliti mengenai analisis faktor memilih jabatan fungsional tenaga kependidikan di Perpustakaan Pusat Universitas Padjadjaran. Peneliti berharap bahwa melalui penelitian ini dapat menjadi bahan masukan bagi Perpustakaan Pusat Universitas Padjadjaran untuk berusaha dalam melakukan peningkatan kualitas pustakawan melalui pengadaan pelatihan yang sesuai kebutuhan pustakawan.

\section{METODE PENELITIAN}

Penelitian ini menggunakan metode kualitatif melalui pendekatan deskriptif. Metode penelitian kualitatif adalah, 
“Metode penelitian yang mencoba mengangkat fenomena di masyarakat. Masyarakat menjadi subjek kajian yang menarik untuk diteliti. Kehidupan masyarakat memiliki sisi yang khas atau unik, misalnya dari perilaku, motivasi, dan lingkungan. Namun, hal ini perlu dianalisis lebih jauh untuk alasan dan bagaimana hal tersebut tercipta di masyarakat. Jadi, penelitian kualitatif merupakan metode penelitian yang mampu menggambarkan lebih mendalam dan menginterpretasikan mengenai masalah atau fenomena di masyarakat melalui uraian kalimat" (Wardiana, Khadijah, \& Rukmana, 2018).

Peneliti dalam penelitian kualitatif harus mampu menggeneralisasikan temuan penelitian. Maka, peneliti pun harus tepat menentukan populasi penelitian. Nopianti, Silvana, and Budiono (2016) menulis bahwa, "Metode deskriptif merupakan suatu metode dalam meneliti status kelompok manusia, objek, kondisi, dan sistem pemikiran. Tujuan dari penelitian deskriptif adalah membuat deskripsi, gambaran atau lukisan secara sistematis, faktual, dan akurat mengenai fakta, sifat serta hubungan fenomena yang diselidiki." Peneliti melalui metode penelitian kualitatif deskriptif dapat menggambarkan fenomena penelitian jabatan fungsional pustakawan di Perpustakaan Pusat Universitas Padjadjaran.

Adapun kegiatan analisis data yang digunakan melalui analisis deskriptif, yakni cara menganalisis data dengan c a r a menggambarkan data yang telah diperoleh tanpa terlebih dahulu membuat simpulan. Selain itu, analisis deskriptif dijelaskan Rohman, Prijana, and CMS (2017) menyatakan,
“Pendekatan kualitatif sendiri merupakan suatu pendekatan dalam melakukan penelitian atau suatu kajianyang berorientasi pada gejalagejala yang bersifat alamiah. Karena orientasinya demikian, maka sifatnya naturalistik dan mendasar atau bersifat kealamiahan serta tidak bisa dilakukan di laboratorium melainkan harus terjun di lapangan".

Jadi, metode analisis deskriptif melalui pendekatan kualitatif, dimaksudkan untuk membuat penggambaran terhadap fenomena sosial tertentu, dengan mengembangkan konsep dan mengumpulkan fakta. Tujuan dari penelitian ini adalah untuk membuat deskripsi, gambaran atau lukisan secara sistematis, faktual dan akurat mengenai fakta, dan sifat fenomena yang diselidiki.

Subjek penelitian ini adalah tenaga kependidikan (TENDIK) baik yang PNS maupun BLU di Perpustakaan Pusat Universitas Padjadjaran, yang memilih jabatan fungsional pustakawan dari program inpassing. Tujuan penelitian sendiri dimaksudkan untuk memperoleh hasil analisis tenaga kependidikan dalam memilih karier sebagai jabatan fungsional pustakawan. Universitas Padjadjaran menjadi pelopor dalam penerapan jabatan fungsional pustakawan sehingga ini menjadi dasar peneliti memilih tempat penelitian sebagai gambaran yang mampu mewakili segenap tenaga kependidikan di seluruh perguruan tinggi di Indonesia. Objek penelitian sendiri adalah faktor yang memotivasi tenaga kependidikan dalam memilih jabatan fungsional pustakawan di Perpustakaan Pusat Universitas Padjadjaran.

Penelitian ini hanya melihat 
fenomena atas variabel yang ada. Metode ini untuk mengamati fenomena yang berkembang di lingkungan para tenaga kependidikan tersebut. Berdasarkan penelitian ini, kemudian dapat berkembang menjadi hipotesis baru, yang selanjutnya dapat diuji kebenarannya untuk mengembangkan dan memahami lebih dalam mengenai faktor yang memotivasi pemilihan jabatan fungsional pustakawan di masa yang akan datang.

Penelitian ini menggunakan analisa kualitatif dari seluruh pertanyaan responden untuk dari kuesioner yang dibagikan. Analisa kualitatif digunakan bertujuan untuk memberikan informasi dari tenaga kependidikan terhadap pertanyaan, sehingga analisis kajian penelitian ini dapat menggambarkan kondisi/tujuan penelitian.

Pengumpulan data dilakukan melalui observasi, wawancara dll. penyebaran kuesioner dilakukan via internet, menggunakan perangkat google document, dari pengiriman terhadap 100 tenaga kependidikan, yang berhasil diperoleh pengembalian jawaban sebanyak 100 orang responden. Penyebaran kuesioner dilakukan mulai tanggal 7 Desember 2017 sampai dengan 15 Desember 2017.

\section{HASIL DAN PEMBAHASAN}

Perpustakaan merupakan salah satu unit kerja di dunia pendidikan. Keberadaannya sangat penting sebagai unsur pendukung keberlangsungan proses belajar mengajar, dan dilakukan sama di dunia pendidikan dasar, menengah, atau perguruan tinggi. Keberadaan perpustakaan sekolah pendidikan dasar dan menengah berbeda dengan perpustakaan perguruan tinggi. Tuntutan perpustakaan perguruan tinggi lebih besar dan lebih kompleks karena harus menyediakan koleksi perpustakaan dalam berbagai bentuk, baik koleksi fisik maupun non fisik, sarana prasarana yang mendukung operasional perpustakaan, dan SDM yang handal dalam menjalankan semua fungsi perpustakaan.

Perpustakaan perguruan tinggi memiliki kedudukan dan posisi dalam menentukan keberhasilan pembelajaran perguruan tinggi tersebut. Perpustakaan perguruan tinggi harus mendukung tridharma perguruan tinggi (pendidikan, penelitian, pengabdian kepada masyarakat), dan membangun civitas akademik yang memiliki kemampuan belajar sepanjang hayat. Secara umum, ada beberapa unsur kegiatan di perpustakaan, mulai dari pencarian dan pengumpulan bahan pustaka dan proses pengolahan bahan pustaka melalui pencatatan, katalogisasi, klasifikasi, entri ke dalam database, penempelan label dan slip buku sampai proses penjajaran koleksi di rak. Setelah itu, proses selanjutnya adalah layanan perpustakaan, yang terbagi menjadi dua sistem, yakni sistem terbuka dan sistem tertutup. Sistem layanan terbuka memungkinkan semua pemustaka untuk melakukan pencarian koleksi langsung ke rak, sedangkan sistem layanan tertutup hanya memperbolehkan pemustaka melakukan pencarian di media pencarian yang disediakan, misalnya Online Public Access Catalogue (OPAC). Adapun pengambilan atau penyediaan koleksi dilakukan oleh pustakawan.

Proses selanjutnya adalah proses pendistribusian pengetahuan di perpustakaan atau diseminasi pengetahuan, di mana berupa kegiatan 
penyebarluasan informasi terkait semua bahan pengetahuan perpustakaan kepada pemustaka yang faktual dan pemustaka potensial yang secara fisik tidak berkunjung ke perpustakaan. Proses berikutnya adalah proses pemeliharaan. Semua koleksi perpustakaan harus memiliki program pemeliharaan yang jelas. Hal ini dilakukan agar koleksi dan sumber pengetahuan bisa tersimpan dalam waktu yang lebih lama dan memberi manfaat yang besar bagi kemajuan bangsa.

Perpustakaan berjalan oleh dukungan SDM yang terbagi ke dalam dua kategori besar, yaitu sumber daya fungsional pustakawan dan sumber daya manusia teknis perpustakaan. Pertama, pejabat fungsional pustakawan adalah sumber daya manusia utama di perpustakaan, di mana posisi, tanggung jawab, dan kiprahnya di perpustakaan akan menentukan arah dan pengembangan perpustakaan. Pejabat fungsional pustakawan biasanya adalah tenaga kependidikan dari pegawai negeri sipil yang diangkat sebagai pejabat fungsional pustakawan.

Adapun perbedaan tenaga kependidikan yang bukan fungsional adalah terletak pada tata fungsi, tata laksana dan lingkup tanggung jawab pekerjaan kepustakawanan. Pejabat fungsional pustakawan sendiri terdiri dari kelompok pejabat fungsional ahli dan pejabat fungsional terampil. Keduanya memiliki uraian tugas dan fungsi khusus sesuai jenjang jabatan masing-masing. Pejabat fungsional memiliki kelebihan dapat melakukan kenaikan pangkat dan jabatan dalam kurun waktu tercepat yaitu dua tahun. Namun, hal ini bisa terealisasi bila pustakawan tersebut mampu mencapai jumlah angka kredit tertentu sesuai kewajiban di jenjang jabatan masingmasing.

Kedua, perpustakaan berjalan atas dukungan staf pelaksana teknis perpustakaan, yakni tenaga kependidikan negeri sipil yang tidak memilih jalur fungsional, atau tenaga kependidikan tetap negeri sipil yang ditugaskan dan ditempatkan di perpustakaan. Tugas dan tanggung jawab tenaga teknis perpustakaan adalah mendukung pekerjaan pustakawan fungsional dari sisi teknis manajerial di lapangan keseharian perpustakaan. Antara para pejabat fungsional dan tenaga teknis perpustakaan tidak bisa dipisahkan. Idealnya, kedua tenaga kependidikan ini dapat disatukan dan diatur sedemikian rupa melalui pembentukan struktur organisasi perpustakaan.

Struktur ini disusun berdasarkan kebutuhan dari sisi pengelola dan kebutuhan perpustakaan dari sisi pemustaka. Pustakawan merupakan sebuah profesi yang memiliki jenjang karier yang khusus, tertata dalam format setiap jenjang jabatan. Pengertian karier sendiri adalah, "Perkembangan dan kemajuan dalam kehidupan, pekerjaan, jabatan, dan sebagainya atau pekerjaan yang memberikan harapan untuk maju"(Badan Pengembangan dan Pembinaan Bahasa Kementerian Pendidikan \& Kebudayaan, 2019). Pustakawan dapat memiliki karier yang bagus bila aktif berkegiatan dalam asosiasi kepustakawanan dan menulis.

Berdasarkan peraturan Kepala Perpustakaan Republik Indonesia nomor 11 Tahun 2015 tentang petunjuk teknis jabatan fungsional pustakawan dan angka kreditnya, 
"Pejabat fungsional Pustakawan yang selanjutnya disebut Pustakawan adalah Pegawai Negeri Sipil yang diberi tugas, tanggung jawab, wewenang, dan hak secara penuh oleh pejabat yang berwenang untuk melakukan kegiatan kepustakawanan pada unit-unit perpustakaan, dokumentasi dan informasi instansi pemerintah dan atau unit tertentu lainnya" (Kromosemito, 2017).

Pejabat fungsional pustakawan yang memiliki kreativitas dan semangat kerja yang baik, didukung perencanaan dan pembagian kerja yang baik akan mampu mengejar dan menaiki jenjang karir sesuai waktu yang disediakan. Namun sebaliknya, pejabat fungsional yang tidak memiliki keterampilan dan semangat juang yang keras, tidak akan mampu bertahan. Apabila pejabat fungsional tersebut bertahan, maka keberadaannya akan terseok-seok dari sisi kemajuan karir. Bahkan, sebenarnya yang lebih utama adalah terancamnya kualitas layanan prima bagi pemustaka.

Perpustakaan Pusat Universitas Padjadjaran didirikan berdasarkan Surat Keputusan Rektor Universitas Padjadjaran tanggal 5 September 1974 No. 72/Kep/Unpad/74, sewaktu Prof. Dr. Mochtar Kusumaatmadja menjabat sebagai rektor. Untuk mengenang jasa dari almarhum Prof. Soeria Atmadja, maka gedung perpustakaan ini diberikan nama Graha Soeria Atmadja. Unit Pelaksana Teknis (UPT) Perpustakaan Universitas Padjadjaran dalam menjalankan fungsinya sebagai sarana belajar mengajar, penelitian, dan pengabdian pada masyarakat dalam menjalankan tri dharma perguruan tinggi senantiasa memberikan pelayanan yang baik kepada civitas akademik dan masyarakat sebagai pemustaka lainnya. Setiap fakultas di lingkungan Universitas Padjadjaran sampai saat ini masih terdapat di berbagai lokasi, di Bandung dan di Jatinangor. Maka, setiap fakultas dan lembaga di lingkungan Universitas Padjadjaran mempunyai perpustakaan masing-masing. Namun dalam pembinaannya, baik koleksi maupun pustakawan berada di bawah koordinasi Perpustakaan Pusat. Berikut ini adalah daftar perpustakaan fakultas yang berada di bawah koordinasi Perpustakaan Pusat Universitas Padjadjaran.

Tabel 1

Fakultas di Universitas Padjadjaran

\begin{tabular}{ll}
\hline No & Fakultas \\
\hline 1 & Fakultas Hukum \\
2 & Fakultas Ekonomi dan Bisnis \\
3 & Fakultas kedokteran \\
4 & Fakultas Matematika dan IPA \\
5 & Fakultas Pertanian \\
6 & Fakultas Kedokteran Gigi \\
7 & Fakultas Ilmu Budaya \\
8 & Fakultas Ilmu Sosial dan Politik \\
9 & Fakultas Psikologi \\
10 & Fakultas Peternakan \\
11 & Fakultas Ilmu Komunikasi \\
12 & Fakultas Keperawatan \\
13 & Fakultas Perikanan dan Ilmu \\
& Kelautan \\
14 & Fakultas Teknologi Industri \\
& Pertanian \\
15 & Fakultas Farmasi \\
16 & Fakultas Teknik Geologi \\
17 & Pascasarjana \\
\hline
\end{tabular}

Sumber: Hasil analisis penelitian, 2018

Jumlah perpustakaan fakultas dan unit kerja di lingkungan Universitas Padjadjaran sebanyak 17 unit. Ketujuh 
belas unit perpustakaan ini harus dikelola dengan baik dan benar. Meskipun wewenang pengelolaan teknis perpustakaan fakultas berada di bawah para dekan sebagai pimpinan unit masingmasing. Selain itu, pengembangan sumber daya manusia dari sisi penambahan keterampilan, wawasan, dan sisi peningkatan karier kerja pustakawan menjadi tanggung jawab perpustakaan pusat Universitas Padjadjaran.

Oleh karena itu, Direktorat Sumber Daya Manusia Universitas Padjadjaran bekerja sama dengan Perpustakaan Pusat untuk melakukan upaya peningkatan kualitas dan sekaligus kuantitas pejabat fungsional pustakawan di lingkungan Universitas Padjadjaran. Ada beberapa kategori pegawai negeri sipil yang mengikuti inpassing, salah satunya adalah jabatan fungsional pustakawan yang usia maksimal 56 tahun untuk jabatan terampil, ahli pertama dan ahli muda, sedangkan untuk yang jabatan ahli madya pada usia 58 tahun. Pegawai negeri sipil dapat mengikuti inpassing apabila telah memenuhi persyaratan yang sudah ditentukan dalam peraturan inpassing. Setelah mengikuti proses inpassing, dan surat keputusan dari kementerian sudah keluar maka pegawai negeri sipil diwajibkan mengikuti diklat dengan pola 150 jam latihan dari lembaga Pembina, Perpustakaan Nasional Republik Indonesia. Namun, bila pegawai negeri sipil tersebut dalam kurun waktu yang sudah ditentukan, dua tahun tidak melakukan diklat maka tenaga kependidikan akan kembali ke posisi awal, jabatan struktural. Inpassing berlaku dua tahun yakni saat Peraturan Menteri PAN-RB ( Permenpan) ditetapkan sampai Desember 2018.

Saat ini, pelaksanaan inpassing disesuaikan dengan Permenpan No. 26 tahun 2016 dan Peraturan Kepala Perpustakaan Nasional Republik Indonesia No. 1 tahun 2017, yang mengalami perubahan ke dalam Permenpan No. 42 tahun 2018 mengenai inpassing. Salah satu perubahan yang mencolok adalah diperpanjangnya masa inpassing sampai tahun 2021. Permenpan No. 42 tahun 2018 ini disusun kemudian dengan Peraturan Kepala Perpustakaan Nasional yang baru No. 3 tahun 2019, yang berisi pengangkatan pertama minimal Diploma Dua (D2) dalam berbagai bidang ilmu. Perkembangan inpassing sekarang, sangat jauh berbeda dengan Peraturan Kepala Perpustakaan Nasional No. 1 tahun 2017, di mana membolehkan minimal pendidikan SMA dengan persyaratan wajib melaksanakan pendidikan dalam kurun waktu lima (5) tahun. Adapun proses inpassing yang mengacu ke Peraturan Kepala Perpustakaan Nasional No. 3 tahun 2018 harus memiliki sertifikat kualifikasi pustakawan dari LSP.

Ketika Universitas Padjadjaran melaksanakan program inpassing a pada tahun 2017 dan pertengahan 2018, ternyata peminatnya sangat banyak. Peserta yang terdaftar berjumlah 165 orang dari berbagai fakultas di lingkungan Universitas Padjadjaran, dan tenaga kependidikan yang mendapat surat keputusan Dikti terdapat 88 orang. Tenaga kependidikan yang memiliki surat keputusan Rektor adalah mereka yang memiliki status non pegawai negeri sipil sehingga hasil dari inpassing tidak bisa keluar surat rekomendasi, melainkan sertifikat telah mengikuti uji kompetensi. Ketika inpassing pertama dibuka, tenaga kependidikan yang mengikuti sangat diuntungkan karena tidak melalui uji 
kompetensi, dan jabatan fungsional pustakawannya diterima.

Tabel 2

Data inpassing 2018

\begin{tabular}{|c|c|c|c|c|c|c|}
\hline \multirow[t]{2}{*}{ No } & \multirow[t]{2}{*}{$\begin{array}{l}\text { Jenjang } \\
\text { jabatan }\end{array}$} & \multicolumn{4}{|c|}{$\begin{array}{l}\text { Kualifikasi } \\
\text { pendidikan }\end{array}$} & \multirow[t]{2}{*}{ Total } \\
\hline & & SL & D & S1 & S2 & \\
\hline 1 & Terampil & 2 & 3 & & & 25 \\
\hline 2 & Mahir & 2 & 5 & & & 26 \\
\hline 3 & Penyelia & & 3 & & & 3 \\
\hline 4 & Ahli & & & 1 & 1 & 12 \\
\hline 5 & $\begin{array}{l}\text { Ahli } \\
\text { Muda }\end{array}$ & & & 1 & 3 & 16 \\
\hline 6 & $\begin{array}{l}\text { Ahli } \\
\text { Madya }\end{array}$ & & & 2 & 4 & 6 \\
\hline & Jumlah & 2 & 8 & 1 & 4 & 88 \\
\hline
\end{tabular}

Sumber: Tim penilai Pustakawan UNPAD, 2018

Pustakawan merupakan sebuah profesi yang membutuhkan sikap profesionalisme. Adapun ciri profesionalisme seorang pustakawan, di antaranya,

"Pertama, memiliki ilmu pengetahuan, keterampilan, kecakapan, dan keahlian yang mumpuni di bidangnya. Kedua, memiliki tingkat kemandirian yang tinggi. Ketiga, memiliki kemampuan untuk berkolaborasi dan bekerja sama.

Keempat, senantiasa berorientasi pada jasa dan menjunjung tinggi kode etik pustakawan. Kelima, senantiasa melihat ke depan atau berorientasi pada masa depan" (Anawati, 2015).

Berdasarkan karakteristik tersebut, pertama pustakawan harus mengetahui potensi yang dimilikinya untuk dikembangkan lebih lanjut. Kedua, pustakawan pun harus memiliki kepercayaan diri yang tinggi agar mandiri saat bekerja dan yakin dalam mencapai keberhasilan. Ketiga, pustakawan mampu bekerja sama dengan pustakawan, kepala perpustakaan, pemustaka, dan pihak luar perpustakaan lainnya dalam berkegiatan. Keempat, pustakawan harus jujur, memegang teguh kode etik profesi pustakawan dan senantiasa ikhlas melayani kebutuhan informasi pemustaka. Kelima, pustakawan dapat mengikuti perkembangan teknologi informasi demi kemajuan perpustakaan.

Maka, pustakawan harus memiliki motivasi kerja yang tinggi agar produktivitas kerja meningkat dan dapat memberikan manfaat yang maksimal bagi pemustaka yang membutuhkan. Pustakawan tidak dapat melepaskan diri dari kenyataan bahwa mereka adalah individu yang juga mempunyai kebutuhan, keinginan, dan harapan dari tempat kerja. Hal ini berkaitan erat dengan motivasi kerja pustakawan yang berbeda-beda dalam menghasilkan pekerjaan yang berkualitas.

Dengan demikian, pustakawan harus memahami ilmu dasar manajemen. Widodo (2012) mengatakan bahwa peran pustakawan sekarang, yaitu: "Information manajer, team work, dan teacher, consultant, atau researcher." Berdasarkan uraian di atas, pustakawan yang ideal memiliki tanggung jawab sebagai perancang, manajer, administrator, rekan kerja, pendidik, pelaku, motivator, pengawas terhadap pustakawan lain, pemustaka, dan sarana serta prasarana perpustakaan, dan sekaligus sebagai pihak yang melakukan evaluasi. Maka, pustakawan harus selalu dinamis dan mampu beradaptasi dengan perkembangan teknologi dalam mempertahankan, dan meningkatkan kualitas pelayanan perpustakaan. Hal ini diharapkan dapat menjadi sumber utama bagi pemustaka dalam mencari informasi, dan mengundang pemustaka lebih banyak 
lagi.

Pustakawan sebagai perancang adalah kemampuan pustakawan dalam merencanakan pengadaan bahan koleksi yang selalu terbaru (up to date) dan lengkap sesuai kebutuhan pemustaka, serta desain ruangan perpustakaan yang nyaman. Hal ini menjadi sesuatu yang tidak mudah karena perlu pemikiran yang dinamis dan inovatif untuk berkembang lebih baik.

Perpustakaan sebagai manajer adalah kemampuan pustakawan dalam mengatur dan mengelola suatu perpustakaan. Dengan demikian, pustakawan bisa memberikan pelayanan yang adil, ramah, dan menyenangkan kepada para pemustaka. Tujuannya adalah meningkatkan minat baca pemustaka dalam rangka meningkatkan kualitas hidup para pemustaka, yakni para mahasiswa yang tidak hanya dituntut pintar, namun juga memiliki janggung jawab, disiplin, dan komunikasi yang baik dengan masyarakat. Hal ini bisa diwujudkan melalui komunikasi yang baik antara pustakawan dengan pemustaka. Kata lain, pustakawan harus memiliki struktur kepemimpinan dalam kegiatan pengelolaan perpustakaan.

Pustakawan sebagai adminstrator adalah kemampuan pustakawan dalam memimpin, menertibkan administrasi baik dari segi penempatan buku yang rapi dan teratur maupun penyimpanan data yang sesuai dengan keberadaan buku. Dengan demikian, pemustaka dapat menerima informasi tentang sesuatu secara mudah. Tetapi, apabila koleksi tersebut belum tersedia, maka pustakawan dapat segera mencarikan rekomendasi koleksi lain yang kajiannya masih berhubungan.

Pustakawan sebagai pelaku adalah kemampuan pustakawan dalam melakukan aktivitas yang sesuai perencanaan yang tertuang dalam visi dan misi perpustakaan. Visi dan misi perpustakaan dapat menjadi tolak ukur dalam melakukan evaluasi, dan menentukan berjalannya visi misi perpustakaan. Pustakawan sebagai rekan kerja adalah kemampuan pustakawan dalam bekerja sama secara harmonis dengan pemustaka dalam "menghidangkan" informasi yang "sehat" sesuai dengan asas manfaat.

Pustakawan sebagai pendidik adalah kemampuan pustakawan dalam memberikan teladan kepada pemustaka baik dalam sikap maupun tindakan. Dengan demikian, pustakawan selalu siap membantu kesulitan yang dihadapi pemustaka dalam kaitannya mencari informasi yang bermanfaat. Pustakawan sebagai motivator adalah kemampuan pustakawan dalam memberikan motivasi kepada sesama pustakawan dan pemustaka. Maka, pustakawan terus mengembangkan diri secara keilmuan mengikuti perkembangan dunia ilmu perpustakaan dan informasi. Pustakawan dapat menyesuaikan diri ke dalam perkembangan informasi dalam pengembangan perpustakaan.

Adapun pustakawan sebagai pengawas adalah kemampuan pustakawan dalam mengawasi kegiatan di perpustakaan yang berkaitan dengan kenyamanan suasana perpustakaan dan keberadaan sumber informasi di suatu perpustakaan. Dengan demikian, pustakawan dapat memantau koleksi perpustakaan tanpa membuat "risih" pemustaka. Pustakawan dapat cepat tanggap menyelesaikan permasalahan yang dihadapi pemustaka, misalnya membantu pemustaka yang belum 
mengembalikan buku sesuai waktu pengembalian sehingga terkena denda dalam jumlah nominal yang cukup besar. Pustakawan dapat mencegah hal ini melalui komunikasi yang baik. Dengan kata lain, berarti pustakawan harus mengawasi hasil kegiatannya apakah sudah sesuai dengan target atau belum?

Pustakawan sebagai pihak yang melakukan evaluasi adalah kemampuan pustakawan dalam menilai kekuatan dan kelemahan, baik atau buruknya suatu pengelolaan suatu perpustakaan di tempat kerja. Dengan demikian, pustakawan bisa mempertahankan keberhasilan pengelolaan yang sudah dicapai dan memperbaiki kegagalan saat pengelolaan perpustakaan. Hal ini, tentu akan menjadi pendorong kemajuan para pemustaka sebagai mahasiswa dalam proses belajar atau sebagai dosen dalam proses mengajar, ataupun tenaga kependidikan di Universitas Padjadjaran dalam mencerdaskan kehidupan bangsa. Pustakawan berarti harus selalu mengadakan penilaian terhadap program yang sudah dijalankan agar dapat meningkatkan kualitas pelayanan kepada pemustaka.

Heriyanto, Yusup, and Rusmana (2013), mengemukakan bahwa selain tanggung jawab pustakawan yang telah dibahas sebelumnya, profesi ini dimaknai berbeda-beda oleh beberapa pustakawan yang menjadi subjek penelitian tersebut. Makna profesi pustakawan dalam penelitian tersebut di antaranya adalah pustakawan sebagai penolong, pustakawan sebagai pendidik, pustakawan sebagai teman diskusi, pustakawan sebagai konsultan, pustakawan sebagai pembimbing, pustakawan sebagai manajer informasi, pustakawan sebagai fasilitator informasi, dan pustakawan sebagai profesi yang menjanjikan.

Menurut UU No. 43 Tahun 2007, pasal 1 ayat 8 dalam Kromosemito (2017), pustakawan adalah, "Seseorang yang memiliki kompetensi melalui pendidikan dan/atau pelatihan kepustakawanan serta mempunyai tugas dan tanggung jawab untuk melaksanakan pengelolaan dan pelayanan perpustakaan". Seseorang dapat dikatakan sebagai pustakawan bila telah menempuh pendidikan kepustakawanan atau pelatihan. Pengangkatan seorang individu melalui pelatihan kepustakawan hingga disebut sebagai pustakawan memiliki alasan tertentu. Hal ini,

"Mengingat kondisi jumlah pustakawan di Indonesia per-Januari 2017 sebanyak 3.179 orang sedangkan jumlah perpustakaan sebanyak 154.359, terdiri dari 121.187 perpustakaan sekolah, 2.428 perpustakaan perguruan tinggi, 23.611 perpustakaan umum, dan 7.132 perpustakaan khusus, sehingga masih diperlukan pustakawan sebanyak 356.049 orang yang tersebar di wilayah Indonesia" (Kepala Perpustakaan Nasional Republik Indonesia, 2017).

Berdasarkan rujukan ini, kebutuhan pustakawan dapat diatasi melalui inpassing terhadap tenaga kependidikan pegawai negeri sipil yang tidak memiliki latar belakang ilmu perpustakaan untuk menjadi seorang pustakawan. Tenaga kependidikan tersebut dapat mengumpulkan berkas administrasi kepada pimpinan unit kerja. Kemudian akan diseleksi oleh pimpinan, dan diajukan secara administrasi kepada Pembina Kepagawaian (PPK) Pusat dan 
Daerah.

Sesuai hasil tersebut maka dapat diketahui bahwa respon rate dari penelitian ini, yaitu: Jumlah kuesioner yang kembali $\rightarrow 100 \times 100 \%=10.000 \%$. Hasil kuesioner dapat diketahui bahwa sudah 52\% pustakawan mengikuti pendidikan yang berhubungan dengan ilmu perpustakaan dan informasi teknologi. Lalu, ada responden yang masih $48 \%$ belum pernah mengikuti pendidikan. Oleh karena itu, saat ini dapat dirancang jenis pelatihan yang akan diberikan kepada kelompok 48\% responden agar pengetahuan mengenai kepustakawanan sebagai meningkat.

Preferensi responden kebanyakan memilih menjadi pustakawan adalah karena minat sendiri berjumlah 85\% responden. Adapun responden berjumlah $12 \%$ menjawab karena dorongan pimpinan, dan 3\% responden menjawab lainnya. Sesuai jawaban responden tersebut, ternyata berhubungan dengan harapan kenaikan upah/gaji yang akan diterima jika memilih jabatan fungsional pustakawan dibandingkan dengan di tempat asalnya. Responden menjawab "ya" berjumlah $71 \%$ dan sisanya $29 \%$ responden beranggapan tidak berhubungan dengan kenaikan gaji. Hal ini menjadi menarik karena ternyata penetapan tunjangan menjadi salah satu alasan pemilihan jabatan fungsional pustakawan. Hal ini berbeda dengan asumsi semula dalam penelitian terdahulu bahwa pemberian insentif tidak berpengaruh pada kinerja atau menjadi suatu hal yang dicari dalam jabatan fungsional pustakawan. Insentif adalah hak tenaga kependidikan dari jabatan fungsional pustakawan. Jadi, dapat dikatakan pemberian insentif bukan merupakan faktor yang memengaruhi (Dinahaji, 2012).

Pekerjaan sebagai pustakawan sudah dikenal oleh para karyawan, karena 97\% mengetahui tentang jabatan fungsional pustakawan, dan hanya 3\% yang belum mengetahui. Responden mengetahui informasi profesi pustakawan dari lingkungan kerja terdapat $41 \%$, 54\% menjawab dari sosialisasi jabatan fungsional pustakawan, 3\% menjawab dari teman, dan hanya $2 \%$ yang menjawab lainnya, yaitu melalui internet, informasi dari peraturan Menteri Pendayagunaan Aparatur Negara (MENPAN), dan peraturan Kepala Perpustakaan Nasional Republik Indonesia. Responden sebanyak 97\% sudah mengetahui tentang pekerjaan sebagai pustakawan, hampir setengahnya mengetahui tentang pustakawan tingkat terampil (46\%), setengahnya (45\%) lagi tingkat ahli dan sisanya $8 \%$ belum menge tahui tentang keduanya. Untuk kelompok terampil, hanya $20 \%$ responden yang tidak mengetahui tentang jabatannya, sedangkan untuk kelompok ahli ada $23 \%$ yang tidak mengetahui. Selain itu, responden sebanyak $73 \%$ meyakini bahwa jabatan fungsional pustakawan akan menjadi karier yang bagus di kemudian hari. Namun, responden berjumlah $27 \%$ agak ragu dengan kondisi jabatan fungsional pustakawan yang akan datang. Responden hampir semuanya siap menghadapi semua konsekuensi setelah memilih jabatan fungsional pustakawan.

\section{SIMPULAN}

Kesimpulan yang didapatkan dari penelitian ini adalah bahwa faktor tenaga kependidikan dalam memilih jabatan fungsional pustakawan di Universitas 
Padjadjaran ada beberapa faktor, di antaranya yaitu faktor minat, dorongan pimpinan dan faktor lain-lain. Selain itu, banyak di antara pegawai negeri sipil memilih jabatan fungsional pustakawan dikarenakan ada peluang untuk lebih cepat naik pangkat/golongan, $\mathrm{d}$ a $\mathrm{n}$ harapan peningkatan penghasilan. Di sisi lain, tenaga pendidik pada dasarnya sudah memiliki keahlian dalam bidang ilmu perpustakaan. Pada intinya, tujuan tenaga pendidik memilih karir sebagai jabatan fungsional adalah untuk mendapatkan jenjang atau karir yang lebih baik dibandingkan kondisi sebelumnya. Rencana penelitian selanjutnya ialah mengukur kinerja tenaga kependidikan dalam jabatan fungsional pustakawan di perpustakaan. Hal ini untuk melihat praktik kepustakawanan langsung di perpustakaan.

\section{DAFTAR PUSTAKA}

Anawati, S. (2015). Profesionalisme pustakawan dalam layanan informasi. Jurnal Pustaka Ilmiah, 1(1), 29-37. Retrieved from https://jurnal.uns.ac.id/jurnalpustak ailmiah/article/view/33100/21836

Badan Pengembangan dan Pembinaan Bahasa Kementerian Pendidikan \& Kebudayaan. (2019). Kamus besar bahasa Indonesia (KBBI). Retrieved June 15, 2019, from https://kbbi.web.id website: https://www.kbbi.web.id/karier

Bryan, J. E. (2016). The preparation of academic librarians who provide instruction: Comparison of first and second career librarians. The Journal of Academic Librarianship, 42(4), 340-354. https://doi.org/10.1016/j.acalib.2016. 05.010

Dinahaji, H. S. (2012). Pengaruh pemberian insentif terhadap kinerja pustakawan di Perpustakaan Daerah Jawa Tengah. Jurnal Ilmu Perpustakaan, 1(1), 133-139. Retrieved from https://ejournal3.undip.ac.id/index. php/jip/article/view/730/706

Heriyanto, Yusup, P. M., \& Rusmana, A. (2013). Makna dan penghayatan profesi pustakawan: Studi fenomenologis terhadap para pustakawan pada perpustakaan perguruan tinggi. Kajian Informasi $\mathcal{E}$ Perpustakaan, 1(2), 147-156. https:// doi.org/10.24198/jkip.v1i2.11 004

Kepala Perpustakaan Nasional Republik Indonesia. Peraturan Kepala Perpustakaan Nasional Republik Indonesia nomor 2 tahun 2017 tentang tata cara pengangkatan pegawai negeri sipil dalam jabatan fungsional pustakawan melalui penyesuaian/inpassing. , Pub. L. No. 2 (2017).

Kromosemito, S. (2017). Jabatan fungsional pustakawan di mata pegawai non pustakawan. Berkala Ilmu Perpustakaan Dan Informasi, 13(1), 64-78. https:// doi.org/10.22146/bip.25968

Martikasari, S. (2012). Pengaruh sistem rotasi kerja terhadap peningkatan kinerja pustakawan di UPT Perpustakaan

Universitas Diponegoro. Jurnal Ilmu Perpustakaan, 1(2), 96-103. Retrieved from https:/ / ejournal3.undip.ac.id/index. php/jip/article/view/672/672

Nopianti, N., Silvana, T., \& Budiono, A. (2016). Sikap pengunjung terhadap ketersediaan layanan di Reading Lights: Studi deskriptif kuantitatif sikap pengunjung terhadap ketersediaan layanan Reading Lights Coffee \& Corner. Kajian Informasi $\mathcal{E}$ 
Perpustakaan, 4(1), 29-36. https://doi.org/10.24198/jkip.v4i1.11 624

Nugrohoadhi, A. (2014). Motivasi kinerja pustakawan Universitas Atma JayaYogyakarta setelah keluarnya jabatan fungsional pustakawan. Jurnal Ilmu Perpustakaan $\mathcal{E} \quad$ Kearsipan Khizanah Al-Hikmah, 2(1), 28-37. Retrieved from http://journal.uinalauddin.ac.id/index.php/khizanahal-hikmah/article/view/138/99

Oliver, A., \& Prosser, E. (2017). Choosing academic librarianship: An examination of characteristics and selection criteria. The Journal of Academic Librarianship, 43(6), 526-531. https://doi.org/10.1016/j.acalib.2017. 08.009

Oliver, A., \& Prosser, E. (2018). Academic librarianship without the degree:

Examining the characteristics and motivations of academic library professionals. The Journal of Academic Librarianship, 44(5), 613-619. https://doi.org/10.1016/j.acalib.2018. 07.006

Rohman, A. S., Prijana, \& CMS, S. (2017). Perluasan notasi Dewey Decimal Classification (DDC) tentang bahasa dan susastra Sunda. Kajian Informasi $\mathcal{E}$ Perpustakaan, 5(2), 155-170. https://doi.org/10.24198/jkip.v5i2.11 014

Wardiana, D., Khadijah, U. L. S., \& Rukmana, E. N. (2018). Dokumentasi budaya ngaruat lembur di Radio RASI FM. Kajian Informasi $\mathcal{E}$ Perpustakaan, 6(1), 43-58. https://doi.org/10.24198/jkip.v6i1.15 325

Widodo. (2012). Peran dan karakteristik pustakawan di era digital library. Seminar Profesionalisme Pustakawan Dalam Era Teknologi Informasi. Surakarta: IPI. 
